\title{
PDGFR Family Gene Mutation
}

National Cancer Institute

\section{Source}

National Cancer Institute. PDGFR Family Gene Mutation. NCI Thesaurus. Code C136417.

A change in the nucleotide sequence in a PDGFR family gene. 